ACTA MYCOLOGICA

Vol. 48 (2): 147-153

2013
Dedicated to Professor Maria Ławrynowicz on the occasion of the 45th anniversary of her scientific activity

DOI: $10.5586 / \mathrm{am} .2013 .017$

\title{
Fungi of the genus Trichosporon isolated from the skin in hospitalized patients
}

\author{
MARIA DYNOWSKA ${ }^{1}$, ANNA BIEDUNKIEWICZ ${ }^{1}$, ELŻBIETA EJDYS ${ }^{1}$ \\ EWA SUCHARZEWSKA ${ }^{1}$, and MAŁGORZATA ROSŁAN ${ }^{2}$
}

\author{
${ }^{1}$ Department of Mycology, Faculty of Biology and Biotechnology \\ University of Warmia and Mazury in Olsztyn \\ Oczapowskiego 1A, PL-10-917 Olsztyn, dynow@uwm.edu.pl \\ ${ }^{2}$ Independent Public Complex of Tuberculosis and Lung Diseases in Olsztyn \\ Jagiellońska 78, PL-10-357 Olsztyn
}

Dynowska M., Biedunkiewicz A., Ejdys E., Sucharzewska E., Rosłan M.: Fungi of the genus Trichosporon isolated from the skin in hospitalized patients. Acta Mycol. 48 (2): 147-153, 2013.

Fungi of the genus Trichosporon are widespread in the biosphere and are a frequent component of the skin mycobiota. They are opportunistic organisms that adopt a commensal lifestyle on the skin in healthy humans but can cause pathological changes (trichosporonosis) of various intensity and range in immunocompromised persons. The species recorded in our study ( $T$. asahii, T. capitatum, T. cutaneum, T. inkin, T. pullulans) are potential anthropopathogens. T. asahii, T. cutaneum and T. inkin are classed as BSL-2 in the biosafety classification.

Key words: mycobiota skin's, opportunistic fungi, Trichosporon, yeasts, Basidiomycota

\section{INTRODUCTION}

The genus Trichosporon was established by Behrendt in 1890 (Barnett, Payne and Yarrow 1990) and included into yeast-like fungi. At present it belongs to yeasts (Kurtzman et al. 2011) and its species are related to Ascomycota and to Basidiomycota (de Hoog et 2000; Kurtzman, Fell 2000). Based on investigations of $18 \mathrm{~S}$ rRNA and 26S rRNA, some species were placed in the genus Geotrichum, family Dipodascaceae, order Saccharomycetales, while a vast majority of other species were included into the anamorphic Basidiomycota, genus Trichosporon (very closely related to Cryptococcus), family Filobasidiaceae, order Tremellales (de Hoog et al. 2000). Teleomorphic stages have not been recorded in species belonging to Basidiomycota. Sexual forms have been described in several species of Ascomycota such as Dipodascus capitatus de Hoog, M. Th. Smith et Guého, which is a sexual stage of Trichosporon capitatum von Arx (Kurnatowska, Kurnatowski 2006). 
While fungi of the genus Trichosporon are euryecological organisms occurring in all climatic zones, each species prefers an ecological niche (de Hoog et al. 2000). The genus mostly includes anthropophiles which prefer the skin and its products but also colonize internal ontocoenoses as well as psychrophilic soil species ( $T$. dulcitum (Berkhout) Weijman, T. sporotrichoides van Oorschot et de Hoog), coprophilic species close to them (T. faecale Guého et $\mathrm{M}$. Th Smith), species preferring eutrophized waters (T. laibachii Guého et M. Th Smith) or clean waters (T. aquatile Hedrick et Dupont), species associated trophically with cap fungi (T. laubieri (Moretz) Weijman) and with birds (T. gracile Guého et M. Th. Smith) (Kurtzman, Fell 2000; Dynowska et al. 2008b).

Fungi of the genus Trichosporon are exogenic saprotrophs which are opportunistic organisms. While they are not causative agents of pathological changes in healthy humans where the systemic balance is stable, they can colonize the human body asymptomatically and adopt a commensal lifestyle. They can attack the host when immunodeficient (Dynowska 1996; Baran 1998; Dynowska et al. 2011). The occurrence of fungi of the genus Trichosporon in biological materials in patients hospitalized for recurring respiratory infections, including suspected tuberculosis, was investigated in this study.

\section{MATERIALS AND METHODS}

Swabs were collected from the skin between fingers (I) and toes (II), and from the groin (III) and underarms (IV) in 50 patients, 25 men and 25 women, hospitalized at the Independent Public Complex of Tuberculosis and Lung Diseases in Olsztyn. Swabs were collected for mycological analysis and procedures used in laboratory diagnostics were followed (Annaisiae, Ginnis and Pfaller 2003; Kurnatowska, Kurnatowski 2006). Fifty healthy persons presenting for a routine medical check-up were the control group.

Fungal macrocultures were conducted on solid and liquid Sabouraud medium with $0.1 \%$ chloramphenicol at $37^{\circ} \mathrm{C}$ for $48-72$ hours. The incubation period was extended to seven days for the solid medium and to three weeks for the liquid medium if fungal growth was not observed. Microcultures were set up on slants coated with a thin film of Nickerson agar enriched with a few drops of 1:1 broth and rabbit serum. The cultures were analyzed under a microscope after 48-72 (120) hours and the following were assessed: morphology of the hyphae, the presence of budding cells, shape, size and distribution of blastospores, arthrospores and chlamydospores. Arthrospores which are the most characteristic spores of the genus Trichosporon and hyphal branching were analyzed in special detail. Fermentation and assimilation abilities of selected sugars and nitric compounds of the fungi were assessed (de Hoog et al. 2000; Kurtzman, Fell 2000).

Keys by de Hoog et al. (2000), Barnett, Payne and Yarrow (1990), Kreger - van Rij (1984), Kurtzman and Fell (2000), Kurtzman, Fell and Boekhout (2011) and specialist publications by Baran (1998) and Kurnatowska and Kurnatowski (2006) were used for identification. 


\section{RESULTS}

A total of 93 isolates of fungi of the genus Trichosporon (46\% of the samples) were identified in hospitalized patients: 57 isolates from men $(61.3 \%)$ and 36 isolates from women (38.7\%). Five species were detected: Trichosporon asahii Nishikawa Shinoda, T. capitatum Diddens et Lodder [= Magnusiomyces capitatus de Hoog et M. Th. Smith], T. cutaneum Ota [= T. beigelii Vuillemin], T. inkin do Carmo-Sousad Van Uden and T. pullulans Diddens et Lodder [= Guehomyces pullulans (Lindner) Fell et Scorzetti] (Tab. 1).

Considerably fewer isolates and species were recorded in the control group. A total of 52 isolates were identified (26\% of the samples): 37 isolates from men (71.1\%) and 15 isolates from women (28.9\%). These belonged to three species: $T$. capitatum, T. cutaneum and T. inkin.

Fungi were isolated more frequently in men than in women in both groups. As many as three species were not isolated in healthy women: T. asahii, T. pullulans and T. inkin. T. asahii and T. pullulans were not isolated in healthy men (Tab. 1). T. cutaneum dominated in all the subjects. The number of its isolates was comparable in the hospitalized group and the healthy subjects: 55 and 42 isolates, respectively. The number of isolates of other species was considerably higher in the patients than the number of isolates recorded in the control group.

It is interesting that T. asahii, T. cutaneum and T. inkin are not included in the biosafety classification of fungi potentially pathogenic to humans (BSL-2) of the European Confederation of Medical Mycology (de Hoog 1996).

\section{Table 1}

Fungi of the genus Trichosporon isolated from hospitalized patients and from healthy persons, segregated by gender, number of isolates of individual species and isolation site:

I (the skin between fingers), II (the skin between toes), III (groin), IV (underarms)

\begin{tabular}{|c|c|c|c|c|}
\hline \multirow[t]{3}{*}{ Species of fungus } & \multicolumn{4}{|c|}{ Number of isolates } \\
\hline & \multicolumn{2}{|c|}{ persons hospitalized } & \multicolumn{2}{|c|}{ healthy people } \\
\hline & women & men & women & men \\
\hline T. asahii & $1(\mathrm{I})$ & $1(\mathrm{I})$ & - & - \\
\hline T. capitatum & $\begin{array}{c}1 \text { (I), } 1 \text { (II), } \\
3 \text { (III), } 1 \text { (IV) }\end{array}$ & $\begin{array}{c}2 \text { (I), } 5 \text { (II), } \\
5 \text { (III), } 1 \text { (IV) }\end{array}$ & $\begin{array}{c}1 \text { (II), } \\
1 \text { (III), } 1 \text { (IV) }\end{array}$ & $\begin{array}{c}2 \text { (II), } \\
1 \text { (III), } 2 \text { (IV) }\end{array}$ \\
\hline T. cutaneum & $\begin{array}{c}5 \text { (I), } 5 \text { (II), } \\
10 \text { (III), } 5 \text { (IV) }\end{array}$ & $\begin{array}{c}5 \text { (I), } 10 \text { (II), } \\
10 \text { (III), } 5 \text { (IV) }\end{array}$ & $\begin{array}{c}4 \text { (I), } 2 \text { (II), } \\
4 \text { (III), } 2 \text { (IV) }\end{array}$ & $\begin{array}{l}10 \text { (I) }, 10 \text { (II), } \\
5 \text { (III), } 5 \text { (IV) }\end{array}$ \\
\hline T. inkin & - & $5(\mathrm{III})$ & - & $2(\mathrm{III})$ \\
\hline T. pullulans & 2 (II), 2 (IV) & $\begin{array}{c}1 \text { (I), } 4 \text { (II), } \\
1 \text { (III), } 2 \text { (IV) }\end{array}$ & - & - \\
\hline \multirow[t]{2}{*}{ Total } & 36 & 57 & 15 & 37 \\
\hline & \multicolumn{2}{|c|}{93} & \multicolumn{2}{|c|}{52} \\
\hline
\end{tabular}

\section{DISCUSSION}

De Hoog (2000) reports nineteen species of the genus Trichosporon and specifies that nine of them can be associated with the human body. Six species are of clinical importance, especially in immunocompromised persons: T. asahii, T. asteroides, T. cutaneum, T. inkin, T. mucoides and T. ovoides. Three of them were isolated in 
our study. T. asahii is especially important in patients with acute leukemia. It is sometimes isolated from pathological changes of the skin, nails (e.g. in complicated onychomycosis, from the lymphatic system, from blood and urine and in patients with inborn defects of the immune system (de Hoog et al. 2000).

Our results confirmed an association of fungi of the genus Trichosporon with patients with a disturbed systemic and cellular homeostasis. They also showed that some species of the genus Trichosporon could colonize the skin on healthy persons. According to Kurnatowska and Kurnatowski (2006), these fungi are associated with human keratin, which closely corresponds with our results. As well as changes within the skin and mucous membranes. Kurnatowska and Kurnatowski (2006) described trichosporonosis in the reproductive and urinary tracts where T. cutaneum was the aetiological agent.

T. cutaneum has the broadest aetiological spectrum. It can be responsible for superficial mycosis, chronic meningitis and spreading infections in HIV carriers, systemic infections in leukaemia patients, in burn victims - after blood transfusion, and in surgical patients where catheters are often an infection route (de Hoog et al. 2000). We have previously identified catheterization as an important source of mycoinfections (Dynowska, Biedunkiewicz 2001). Although systemic infections caused by $T$. cutaneum are rare, their course is usually terminal. The species poses a special danger to tunic-free bedsore wounds and delayed-healing wounds, so-called "silent" post-operative infections. These wounds contain a high amount of protein in the serum and dead tissues which are a highly suitable substrate for the growth and multiplication of fungi. Infected wounds are one of the sources of nosocomial infections (Dynowska, Góralska and Rosłan 2008a). Observations show that T. cutaneum is one of the dominants in the mycobiota in hospital rooms (Dynowska, Pacyńska and Karaszewska 2008c) and it exhibits increasing expansiveness towards organ ontocoenoses in humans, especially in hospitalized patients (Swoboda-Kopeć et al. 2001). Its prevalence in the respiratory system is high (Dynowska 1993). It was often isolated from the oral cavity, sputum and bronchoscopic fluid in persons diagnosed with cancer of the respiratory system and suspected of tuberculosis (Dynowska, Biedunkiewicz and Sucharzewska 2002). High prevalence of multifocal infections was observed in this group of patients (Dynowska, Ejdys and Kisicka 2004). Reconnaissance studies (Dynowska et al. 2008b) of endoscopic material from persons with unidentified digestive system complaints show that the species has also colonized this ecological niche.

T. capitatum is listed by Kurtzmann and Fell (2000) as a species that can colonize the oral cavity and the digestive tract. It was isolated relatively frequently from the respiratory tract (Dynowska 1993). T. capitatum was detected in the sputum and on the skin of healthy humans but it may be an aetiological factor of terminal systemic mycosis (Baran 1998). It has been shown to occur at different sites on the skin in healthy humans (except hands).

Our results confirmed that T. pullulans rarely occurred on the skin and it was isolated only from patients. It is mostly reported from the oral cavity and different sections of the respiratory tract (Dynowska 1993, 1996). It accompanies T. cutaneum in our study.

T. inkin, reported as a potentially pathogenic species only in the Polish literature (Kurnatowska, Kurnatowski 2006), is especially interesting. It was recorded in 
hospitalized and healthy men in our study. It seems to be gender-specific and associated with men. This is also suggested in studies by other authors (Lopes et. al. 1997; Guého et al. 1994) who stressed its broad aetiological spectrum: from dermatomycosis, especially of damaged skin, to infections of the urinary tracts and terminal sections of the digestive tract, to endocarditis.

Drutz (1986) emphasized the risk of infection of organ ontocoenoses by T. cutaneum, T. capitatum and T. pullulans as early as over 20 years ago. According to Drutz (1986), these species are widespread in the biosphere and are a frequent component of the skin mycobiota. They can penetrate the oral and nasal cavities from the skin and transfer into to the ontosphere from there. It is disconcerting that as many as three species of the five species isolated by us are classified as BSL-2. This category comprises fungi colonizing organisms of invertebrates and vertebrates, with a high ability to survive in tissues of different organs, that can cause deep-seated opportunistic infections in immunocompromized persons (de Hoog 1996). According to Annaisiae et al. (2003), fungi of the genus Trichosporon prefer sites around the groin, sexual organs and the anus. Piedra alba, a chronic infection of the hair in different parts of the body, as well as infections of nails and mucous membranes of the oral cavity are very common infections caused by fungi of the genus Trichosporon, mostly T. cutanum and T. inkin, in the tropical and subtropical climates (Richardson, Warnock 1993). Due to intensive tourism these diseases and their causal agents can be unintentionally introduced to our climatic zone. The risk of infection by new species of fungi increases as they widen the area of their occurrence in the biosphere and penetrate the human ontosphere (Dynowska 1996; Dynowska, Biedunkiewicz 2001; Dynowska et al. 2008b).

\section{CONCLUSIONS}

Human skin should be treated as a natural reservoir of potentially pathogenic fungi. As well as being inhabited by typical dermatophytes, it is colonized by numerous yeasts. Fungi of the genus Trichosporon seem to be of primary importance.

\section{REFERENCES}

Annaisiae E.J., Mc Ginnis M.R., Pfaller M.A. 2003. Clinical Mycology. Els. Scien. and Church. Leving, New York, Edinburgh, London, Philadelphia.

Baran E. (ed.) 1998. Zarys mikologii lekarskiej. Volumed - Wrocław.

Barnett J.A., Payne R., Yarrow D. 1990. Yeast: characteristic and identification. Cambridge University Press, Cambridge.

de Hoog G.S. 1996. Risk assessment of fungi report from human and animals. Mycoses 39:407-417.

de Hoog G.S., Guarro J., Gené J., Figueras M.J. 2000. Atlas of Clinical Fungi. Centraalbureau voor Schimmelcultures, Utrecht, Univ. Rovira i Virgili, Reus, Spain.

Drutz D.J. 1986. Opportunistic pulmonary mycoses. Respiratory Infections. Church. Leving, New York, Edinburgh, London, Melbourne: 293-316.

Dynowska M. 1993. Changes in mycoflora of man's respiratory system - observed during last some years - yeasts. Acta Mycol. 28 (2): 151-155.

Dynowska M. 1996. Trichosporon species isolated from human respiratory system. Acta Mycol. 31 (2): 137-141. 
Dynowska M., Biedunkiewicz A. 2001. Grzyby chorobotwórcze o wzrastającej ekspansywności. Wiad. Parazyt. 47 (4): 609-613.

Dynowska M., Biedunkiewicz A., Sucharzewska E. 2002. Participation of yeast-like fungi in respiratory system diseases tuberculosis and neoplasms. Acta Mycol. 37 (1/2): 117-122.

Dynowska M., Ejdys E., Kisicka I. 2004. Suscebility to antyfungal agents of yeast - like fungi and yeast isolated from people with multifocal infections. Mikol. Lek. 11 (1):15-19.

Dynowska M., Góralska K., Rosłan M. 2008a. Udział grzybów drożdżopodobnych w zakażeniach szpitalnych. Mikol. Lek. 15 (3): 151-154.

Dynowska M., Góralska K., Szewczyk T., Buczyńska E. 2008b. Godne uwagi gatunki grzybów izolowane z przewodu pokarmowego osób poddawanych endoskopii - badania rekonesansowe. Mikol. Lek. 15 (2): 80-83.

Dynowska M., Pacyńska J., Karaszewska H. 2008c. Ocena mikologiczna szpitalnego laboratorium diagnostycznego. (In:) J. Garbacz (ed.). Diagnozowanie stanu środowiska. Prace Komisji Ekologii i Ochrony Środowiska BTN: 47-54.

Dynowska M., Góralska K., Troska P., Barańska G., Biedunkiewicz A., Ejdys E., Sucharzewska E. 2011. Results of long-standing mycological analyses of biological materials originating from selected organ ontocenoses-yeast and yeast-like fungi. Wiad. Parazyt. 57 (2): 97-102.

Guého E., Improvisi G. S., de Hoog G. S., Dupont B. 1994. Trichosporon on humans: a practical account. Mycoses 37: 3-10. http://dx.doi.org/10.1111\%2Fj.1439-0507.1994.tb00277.x

Kurnatowska A., Kurnatowski P. 2006. Mikologia medyczna. Promedi - Łódź.

Kurtzman C.P., Fell J.W. 2000. The Yeast. A taxonomic study. 4 $^{\text {th }}$ ed., Elsevier - Amsterdam.

Kurtzman C.P., Fell J.W., Boekhout T. 2011. The Yeast. A taxonomic study. $5^{\text {th }}$ ed. Elsevier - Tokyo.

Lopes J.O., Alves S.H., Klock C., Oliveira T.L.O., Forno N.R.F. 1997. Trichosporon inkin peritonitis during continuous ambulatory peritoneal dialysis bibliography review. Mycopathol. 139: 15-18. http:// dx.doi.org/10.1023\%2FA\%3A1006870017725

Richardson M.D., Warnock D.W. 1993. Fungal Infection. Diagnosis and Management. Blackwell Scien. Publ. - Oxford.

Swoboda-Kopeć E., Rakosz A., Sawicka-Grzelak A., Wróblewska M., Krawczyk E., Stelmach E., Łuczak M. 2001. Etiologiczne czynniki fungemii u hospitalizowanych pacjentów. Med. Dośw. Mikrobiol. 53: 291-295.

\section{Grzyby z rodzaju Trichosporon izolowane ze skóry osób hospitalizowanych}

\section{Streszczenie}

Grzyby z rodzaju Trichosporon są szeroko rozpowszechnione w biosferze i stanowią częsty komponent mykobioty skóry (powinowactwo do keratyny ludzkiej). Z niej mogą dostawać się do jamy ustnej, jam nosa a następnie przenosić się w głąb ontosfery. Jako formy oportunistyczne u osób zdrowych prowadzą komensaliczny tryb życia, u osób z zaburzeniami odporności mogą wywoływać zmiany chorobowe (trychosporonozy) o różnym nasileniu i różnym zasięgu. Oprócz skóry i błon śluzowych najczęściej atakowany jest układ moczowy i płciowy a jako droga zakażenia wymieniane są cewniki. Odnotowano przypadki zakażeń układowych kończących się śmiercią. Grzyby z rodzaju Trichosporon są szczególnie niebezpieczne dla trudno gojących się ran chirurgicznych i ran odleżynowych.

Materiał badawczy stanowiły wymazy ze skóry między palcami rąk i nóg oraz pachwin i pach 50 pacjentów (25 kobiet i 25 mężczyzn) SPZG i ChP w Olsztynie (hospitalizacja z powodu nawracających infekcji układu oddechowego, w tym podejrzeniami o gruźlicę). Grupą kontrolną było 50 osób zdrowych, zgłaszających się na badania okresowe. Analizy laborato- 
ryjne i oznaczanie grzybów do gatunku przeprowadzono zgodnie z ogólnie przyjętym tokiem diagnostycznym w laboratoriach mykologicznych.

Od pacjentów hospitalizowanych uzyskano 93 izolaty grzybów z rodzaju Trichosporon należące do 5 gatunków: T. asahii, T. capitatum, T. cutaneum. T. inkin i T. pullulans. W grupie kontrolnej uzyskano 52 izolaty reprezentujące 3 gatunki: T. capitatum, T. cutaneum i T. inkin. W obydwu grupach grzyby częściej notowano u mężczyzn niż u kobiet. Zdecydowanym dominantem był T. cutaneum - liczba jego izolatów u osób hospitalizowanych i zdrowych była porównywalna. W przypadku pozostałych gatunków liczba izolatów uzyskanych od osób hospitalizowanych znacznie przewyższała liczbę izolatów stwierdzonych w grupie kontrolnej. Wszystkie gatunki odnotowane w przeprowadzonych badaniach należą do potencjalnych antropopatogenów, a T. asahii, T. cutaneum i T. inkin są uwzględnione w klasyfikacji biobezpieczeństwa $z$ kategorią BSL-2. W tej kategorii znajdują się grzyby zasiedlające organizmy bezkręgowców i kręgowców, o dużej zdolności przeżywania w tkankach różnych narządów, mogące wywoływać głębokie oportunistyczne zakażenia.

Reasumując, skórę człowieka należy traktować jako jeden z naturalnych rezerwuarów mikrogrzybów potencjalnie chorobotwórczych. Oprócz typowych dermatofitów jest ona siedliskiem licznych drożdży, wśród których grzyby z rodzaju Trichosporon wydają się odgrywać pierwszoplanową rolę. 